\title{
Abnormal Distribution of ABO Blood Groups in Infantile Pyloric Stenosis
}

\author{
J. A. DODGE \\ From the Nuffield Department of Child Health, Queen's University, Belfast
}

A previous communication reported observations on the distribution of $\mathrm{ABO}$ blood groups among 303 infants with hypertrophic pyloric stenosis (Dodge, 1967). This series has now been extended and the earlier observations confirmed.

\section{Materials}

All infants with pyloric stenosis from the Greater Belfast area who are treated surgically must be seen at one of three hospitals, viz, the Royal Belfast Hospital for Sick Children, Belfast City Hospital, and the Ulster Hospital. The medical records of these hospitals for the two decades 1950-69 were examined, and attempts made to trace the 526 patients submitted to Rammstedt's operation. Patients treated medically were excluded on the grounds that the diagnosis had not been completely proven; but they form a relatively small number because the local medical custom is to operate in the great majority of cases. A total of 480 patients were traced, a follow-up rate of $91.3 \%$. Thirty of the 46 patients remaining untraced are known to have emigrated. In the course of subsequent examination, blood samples were taken from each patient either by venepuncture or heel stab after the parents' consent had been obtained. Blood group data from a further 6 were available from the hospital records. Saliva was obtained from 465 patients for determination of the ABO secretor status.

Control blood group data were obtained from the Serological Population Genetics Laboratory (A. C. Kopec, personal communication), and these were used in the preliminary communication (Dodge, 1967). These data were derived from retrospective study of the Northern Ireland Blood Transfusion register of blood donors up to 1960, and as far as Belfast is concerned included 27,757 individuals. In spite of the large size of this series, it was felt to be unsatisfactory in as much as the former policy of using group $O$ Rhesus-negative blood for patients of other groups could have led to an excess of $\mathrm{O}$ Rhesus-negative donors being retained upon the, register. A smaller series, confined to current donors was used by Macafee (1964) and by Johnson et al (1964) as control data for studies of blood groups in diabetes mellitus and gastric ulcers respectively. This series

Received 10 March 1971. showed a lower incidence of group $O$, and a higher proportion of group A, than the larger series obtained from Dr Kopec. Because of this discrepancy, it was decided to examine a further control series. The blood group distribution of 1495 consecutive patients born since 1950 who were admitted to Belfast hospitals for tonsillectomy and adenoidectomy in 1966-68 was ascertained from their case records. All were living in the Greater Belfast area. The data thus obtained from these various sources are compared in Table I. It is clear that the large series from the Serological Population Genetics Laboratory differs considerably from the others.

TABLE I

COMPARISON OF BLOOD GROUP DISTRIBUTION IN DIFFERENT CONTROL GROUPS

\begin{tabular}{|c|c|c|c|}
\hline Group & $\begin{array}{c}\text { A. C. Kopeć } \\
\text { (personal } \\
\text { communication, } \\
1967)\end{array}$ & Macafee (1964) & $\begin{array}{c}\text { Tonsillectomy } \\
\text { and } \\
\text { Adenoidectomy } \\
(1966-68)\end{array}$ \\
\hline & Number Tested & Number Tested & Number Tested \\
\hline $\begin{array}{l}\mathbf{O} \\
\mathbf{A} \\
\mathbf{B} \\
\mathbf{A B}\end{array}$ & $\begin{array}{c}15,269(55 \cdot 01 \%) \\
9,168(33.03 \%) \\
2,624(9.45 \%) \\
696(2.51 \%)\end{array}$ & $\begin{array}{c}5,522\left(48 \cdot 75^{\circ}\right) \\
4,192(37 \cdot 01 \%) \\
1,229\left(10 \cdot 85^{\circ} \%\right) \\
384(3 \cdot 39 \%)\end{array}$ & $\begin{array}{c}719\left(48.09^{\circ}{ }^{\circ}\right) \\
573\left(38.32^{\circ}{ }^{\circ}\right) \\
157\left(10.51^{\circ}{ }^{\circ}\right) \\
46\left(3.08^{\circ}{ }_{\circ}^{\circ}\right)\end{array}$ \\
\hline Total & $27,757(100 \%)$ & $11,327(100 \%)$ & $1,495\left(100_{0}^{\circ}\right)$ \\
\hline
\end{tabular}

The data of Macafee and from the tonsillectomy and adenoidectomy series are very similar $\left(\chi^{2}=0 \cdot 144\right)$; indeed the latter group was investigated because it was thought unlikely that children undergoing tonsillectomy would differ from the general population in respect of blood groups. There is evidence that blood donors are not ideal control subjects inasmuch as group $\mathbf{O}$ donors tend to be more numerous than the incidence of group $\mathrm{O}$ in the general population would predict, and that this excess of group $\mathrm{O}$ in donor series is of the order of 3-4\% (Jorgensen, 1967). For these reasons it was decided that the most appropriate control series was that which was closest in age group to the patients with pyloric stenosis, viz, the tonsillectomy and adenoidectomy series.

Salivary secretor status was also investigated in patients with pyloric stenosis, and control data were obtained from 96 children admitted to hospital for 
tonsillectomy or adenoidectomy and from 435 children attending school dental clinics in Belfast.

\section{Methods}

$\mathrm{ABO}$ and Rhesus blood groups were determined using the tube method. Secretor status of the saliva was determined as previously described using $\mathbf{A}$ and $\mathbf{B}$ antisera and anti-H obtained from the seeds of Ulex europaeus.

\section{Results}

The distribution of $\mathrm{ABO}$ blood groups among 486 patients with infantile hypertrophic pyloric stenosis compared with controls is shown in Table II. It is evident that the proportions of both groups $O$ and $B$ are increased at the expense of group $A$, and that these findings are statistically significant. The relative incidence of pyloric stenosis in children of groups $\mathrm{O}$ and $\mathrm{B}$ compared with group $\mathbf{A}$ is given in Table III.

\section{TABLE II}

\section{DISTRIBUTION OF ABO BLOOD GROUPS IN 486 PATIENTS WITH INFANTILE HYPERTROPHIC PYLORIC STENOSIS (IHPS) COMPARED WITH DISTRIBUTION IN CONTROLS}

\begin{tabular}{|c|c|c|}
\hline \multirow[t]{2}{*}{ Group } & Patients with IHPS & $\begin{array}{l}\text { Tonsillectomy } \\
\text { and } \\
\text { Adenoidectomy Controls }\end{array}$ \\
\hline & Total No. & Total No. \\
\hline $\begin{array}{l}\mathrm{O} \\
\mathrm{A} \\
\mathrm{B} \\
\mathrm{AB} \\
\end{array}$ & $\begin{array}{c}271\left(55 \cdot 76^{\circ}{ }_{0}\right) \\
130(26.75 \%) \\
71(14.61 \% \%) \\
14(2 \cdot 88 \%)\end{array}$ & $\begin{array}{c}719(48.09 \%) \\
573(38.32 \%) \\
157(10.51 \%) \\
46(3.08 \%)\end{array}$ \\
\hline Total & $486(100 \%)$ & $1495(100 \%)$ \\
\hline
\end{tabular}

$\chi^{2}=30.4, \mathrm{df}=3, \mathrm{p}<0.001$.

\section{TABLE III}

RELATIVE INCIDENCE OF INFANTILE HYPERTROPHIC PYLORIC STENOSIS IN CHILDREN OF GROUPS O AND B COMPARED WITH INCIDENCE OF 1.0 IN CHILDREN OF GROUP A

\begin{tabular}{c|c|c|c}
\hline Group & Relative Incidence & $x^{2}$ & $\mathrm{p}$ \\
\hline $\mathrm{O}$ & 1.66 & 20.7970 & $<0.001$ \\
$\mathrm{~B}$ & 1.99 & 17.1322 & $<0.001$ \\
\hline
\end{tabular}

$\chi^{2}$ was calculated by the method of Woolf (1955).

The proportion of salivary non-secretors among patients with pyloric stenosis was lower than expected from the control series but the difference did not reach the 5\% significance level (Table IV). The observed incidence of non-secretors is close to the proportion found in other series. Thus 'we feel sure that the right answer is that just over $22 \%$ of European people of all groups indifferently are non-secretors: this opinion is based on the results of some thousands of tests with anti-Le ${ }^{a}$ serum' (Race and Sanger, 1954).

\section{TABLE IV}

DISTRIBUTION OF ABH SECRETOR STATUS IN 465 PATIENTS WITH INFANTILE HYPERTROPHIC PYLORIC STENOSIS COMPARED WITH 531 CONTROLS

\begin{tabular}{l|l|l}
\hline & IHPS & Controls \\
\hline Secretor & $362(77 \cdot 81 \%)$ & $390(73 \cdot 45 \%)$ \\
Non-secretor & $103(22 \cdot 19 \%)$ & $141(26.55 \%)$ \\
\hline Total & $465(100 \%)$ & $531(100 \%)$ \\
\hline
\end{tabular}

$\chi^{2}=2 \cdot 48, \mathrm{df}=1,0 \cdot 20>p>0 \cdot 10$

The secretor status of the blood group controls is not known.

Rhesus blood groups were also investigated. There were 94 Rhesus-negative children in the series with pyloric stenosis, an incidence of $19 \cdot 35 \%$. This compares with an incidence of $19.06 \%$ Rhesus-negative children in the control series. Clearly, there is no significant difference between the two series in this respect.

\section{Discussion}

These augmented data confirm the previous observation of a significant excess of group $O$ and $B$ compared with group A. Group A individuals behave differently from those of $\mathrm{O}$ and $\mathrm{B}$ in at least one other important respect, viz, the secretion of acid and alkaline phosphatases by the small intestine. It has been shown, for example, that persons of groups $A$ and $A B$ secrete more acid phosphatase, and absorb fat more rapidly, than persons of groups $O$ and B (Beckman, 1969). A possible corollary from this observation might be that the relatively slow absorption of fat from the duodenum in infants of groups $\mathrm{O}$ and $\mathrm{B}$ would prolong the inhibitory effect of intraluminal fat on gastric emptying. It is conceivable that such an effect may contribute to the functional obstruction at the pylorus which sometimes appears to precede organic pyloric hypertrophy.

The difference between patients and controls in respect of salivary secretion of blood group substances was not statistically significant but a slightly higher incidence of secretors was encountered among the patients. Because no control series giving both blood group and secretor status is available, it was not possible to determine whether blood group/secretor combinations differed from those 
expected. A study of intestinal acid and alkaline phosphatases in infantile hypertrophic pyloric stenosis would be of considerable interest.

\section{Summary}

The blood group distribution of 486 patients with infantile hypertrophic pyloric stenosis in the Belfast area showed an excess of groups $O$ and $B$ and a corresponding deficiency of group $A$ and $A B$ by comparison with controls. This observation of a difference between groups $\mathrm{O}$ and $\mathrm{B}$ compared with $A$ and $A B$ is similar to the differential secretion of intestinal phosphatases and suggests a possible association between the development of pyloric stenosis and the efficiency of fat absorption in the infant.
No significant alterations were observed in the distribution of $\mathrm{Rh}$ blood groups or of salivary $\mathrm{ABO}$ secretor status.

\section{REFERENCES}

Beckman, L. (1969). Blood-groups and serum lipids and phosphatases. Lancet, 2, 799.

Dodge, J. A. (1967). ABO blood groups and infantile hypertrophic pyloric stenosis. British Medical fournal, 4, 781-782.

Johnson, H., Daintree, Love, A. H. G., Rogers, N. C., and Wyatt, A. P. (1964). Gastric ulcers, blood groups, and acid secretion. Gut, 5, 402-411.

Jorgensen, G. (1967). The ABO blood group-polymorphism in the multifactorial genetic system. Humangenetik, 3, 264-268.

Macafee, A. L. (1964). Blood groups and diabetes mellitus. Fournal of Clinical Pathology, 17, 39-41.

Race, R. R. and Sanger, R. (1954). Blood Groups in Man, 2nd ed., p. 48. Blackwell, Oxford.

Woolf, B. (1955). On estimating the relation between blood group and disease. Annals of Human Genetics, 19, 251-253. 